\title{
The Realization of Gardner's Multiple Intelligences (MI) Theory in Second Language Acquisition (SLA)
}

\author{
Parviz Maftoon \\ Department of English, Science and Research Branch, Islamic Azad University, Tehran, Iran \\ Email: pmaftoon@srbiau.ac.ir \\ Saeid Najafi Sarem (Corresponding author) \\ Department of English, Hamedan Branch, Islamic Azad University, Hamedan, Iran \\ Email: s_najafisarem@yahoo.com
}

\begin{abstract}
Better understanding of individual cognitive factors that account for successful second language acquisition/learning is an important goal and of great interest for many researchers in the field of language study. Gardner's (1983) Multiple Intelligences Theory has proved that intelligence, as an individual cognitive factor, has a significant influence on the process of SLA and can account for the learners' variation in second language learning. The theory of Multiple Intelligences has caused some educators and language researchers to reassess classroom practices both in education in general and in many areas of language teaching and learning in specific. Before investigating the effect of this important factor, a comprehensive understanding of the term seems to be essential. Therefore, through a detailed literature review, this paper is an attempt to outline the concept of intelligence as well as the role of intelligence in major SLA approaches. Moreover, Gardner's theory of Multiple Intelligences is outlined and its key features are discussed in detail through this paper. Finally, drawing on the role of Multiple Intelligences, this paper tries to elucidate the applications and implications of this theory in relation to second language teaching and learning. This should enable a clearer picture to emerge about the relative importance of intelligence among the constellation of factors associated with second language acquisition.
\end{abstract}

Index Terms-intelligence, Multiple Intelligences Theory, SLA

\section{INTRODUCTION}

Taking a look at the history of language teaching and learning, one can recognize that the $19^{\text {th }}$ century has been highlighted with a significant shift of focus in language education from teaching to learning. This change created an explosion of research aimed at investigating learner characteristics and language acquisition. Learners were paid more attention as the key element in language teaching and learning, and as a result, a plethora of studies emerged focusing on language learners' different characteristics as well as examining the effect of these features on the ease and the speed of acquiring a second language.

According to Ellis (1985) second language (L2) learners are different. They learn with different speed and different results. There are many explanations for that issue. The general factors that influence second language learning are: age, aptitude and intelligence, cognitive style, attitudes, motivation and personality. In recent years, there has been a substantial amount of interest in individual differences among foreign language learners. Although there are many ways in which learners can vary, intelligence is often thought to be one of the most significant predictors of language learning success. According to Gardner's (1983) theory of "multiple intelligences", people vary in terms of eight types of intelligence, namely visual, verbal, mathematical, kinaesthetic, interpersonal, intrapersonal, naturalistic, and rhythmic intelligence. It has been said that each of these types of intelligence may have a bearing, not only on a student's ability to learn a foreign language, but also on the teacher's tendency to favour a given teaching method. Individuals differ from one another in their ability to understand complex ideas, to adapt effectively to the environment, to learn from experience, to engage in various forms of reasoning, to overcome obstacles by taking thought. Although these individual differences can be substantial, they are never entirely consistent: a given person's intellectual performance will vary on different occasions, in different domains, as judged by different criteria. Concepts of "intelligence" are attempts to clarify and organize this complex set of phenomena. In the area of second language learning as Spolsky (1989) states it is assumed that some people are gifted and they learn foreign languages with ease. It was observed that learners acquire a language with different results despite the fact that they are at the same age and are equally motivated. Intelligence is considered by many researchers as an important factor which can account for such differences. Accordingly, with regard to these points, this paper is an attempt to present a detailed picture of Gardner's multiple 
intelligences (MI) theory as well as some important related issues including the role of intelligence in different SLA approaches and finally the applications and implications of multiple intelligences to English language teaching.

\section{DEFINITION AND CHARACTERIZATION OF INTELLIGENCE}

Thanks to its important role in language learning, many researchers have proposed different definitions for intelligence. According to Moaafian (2008, cited in Hernandez et al., 2010) intelligence is a very general mental capability that, among other things, involves the ability to reason, plan, solve problems, comprehend complex ideas, learn quickly and learn from experience. It is not merely book learning, a narrow academic skill, or test-taking smarts. Rather, it reflects a broader and deeper capability for comprehending our surroundings- "catching on", "making sense" of things, or "figuring out" what to do. Chastain (1988, p. 43) refers to the definition of intelligence proposed by Wagner and Sternberg (1985). They discuss three conceptions of intelligence and the implications for education. The first, psychometric view equates intelligence with mental capacity and accepts the position that by means of carefully prepared tests educators can measure that mental ability and use the results to rank learners according to their ability. The second, the Piagetian view, defines intelligence in terms of stages of development based on maturity, experiences in the physical environment, expressed in the social environment, and the individual self-regulatory processes. The third, the information processing view, focuses on the way the brain represents and processes information. The first two views have to do with the brain's capacity; the third deals with what the brain does during learning. Ellis (2008) points out that "intelligence, working memory, and language aptitude are clearly all closely linked. They all refer to cognitive capacities and the difference between their conceptualizations lies largely in how broad and how language-specific the terms are" (p. 649). Sternberg $(1985,2002)$ distinguishes three types of intelligence - analytical (the ability to analyze, compare, and evaluate), creative (the ability to produce novel solutions to problems), and practical (the capacity to adapt, to shape, and to select environments suited to one's abilities). Gardner (1983, p.81) defines "intelligence as the ability to solve problems or to create fashion products that are valued within one or more cultural settings". This definition challenged the traditional psychological view of intelligence as a single capacity that drives logical and mathematical thought. In the same direction, Gardner (1993) described intelligence as a bio-psychological potential that could be influenced by experience, culture, and motivational factors. Elsewhere, Gardner (2009, p. 323) defines intelligence as " a set of skills of problem-solving enabling the individual to resolve genuine problems or difficulties that he or she encounters..., to create an effective product, and ... the potential for finding or creating problems thereby laying the groundwork for the acquisition of new knowledge".

\section{MultiPle InTELligenCeS (MI) TheORY}

The theory of multiple intelligences was proposed by Howard Gardner in 1983. Gardner's (1983) theory of multiple intelligences (MI) proposes a means to understanding the many ways in which human beings are intelligent; that is, how we process, learn, and remember information. Gardner (1983) states that while individuals are capable of processing information in at least seven different ways; each individual varies in the degree of skill possessed in each of these intelligences. He identifies seven categories of skills and abilities which he considers to be individual intelligences: linguistic, logical-mathematical, spatial, bodily-kinesthetic, musical, interpersonal and intrapersonal. He believes that these discrete abilities operate together in complex ways, and provide a much more comprehensive view of what constitutes human intelligence. Of course, later he added an eight and a ninth type to the list namely naturalistic and existential intelligences. Through the theory of multiple intelligences, we can seek to address students' diverse intelligences by creating individualized learning environments. The main focus of this theory is on the content and products of learning. An interesting aspect of this theory is that intelligences that are different can still be easily identified through common life experiences (Gardner, 1993). Educators are always concerned about what educational methods can benefit the learners the most. Gardner's (1993) Multiple Intelligences Theory is potentially one of them. Gardner claimed that educational methods should be created and adjusted to be more flexible for students who have different intellectual capacities, and should be redesigned and rearranged to use the multiple intelligences effectively so that those changes would benefit students, teachers and society. Multiple intelligence theory suggests that there is not just one concrete measure of intelligence and by implication a single way of teaching. Based on Gardner's theory, Chapman and Freeman (1996) draw three implications. Firstly, intelligence can be taught or at least enhanced through teaching. Secondly, intelligences are changing throughout life. Thirdly, the existence of different intelligences that different learners possess results in different learning styles and different needs.

According to Armstrong (2009, p. 27) whether intelligence can develop depends upon three main factors. (1) Biological endowment-including hereditary or genetic factors and insults or injuries to the brain before, during, and after birth. (2) Personal life history-including experiences with parents, teachers, peers, friends, and others who awaken intelligences, keep them from developing, or actively repress them. (3) Cultural and historical backgroundincluding the time and place in which you were born and raised and the nature and state of cultural or historical developments in different domains. We can see the interaction of these factors in the life of Wolfgang Amadeus Mozart.

What follows is a brief description of each type of Gardner's multiple intelligences theory provided mostly by Gardner $(1983,1993)$ and Champen and Freeman (1996). It should be noted that it is not assumed that each type of 
intelligence is ever active in isolation. Gardner (1993) indeed suggests that during a learning episode it will be normal for a number of intelligences to be used together. In fact, he suggests that all intelligences are needed to function productively in society.

\section{A. Verbal/Linguistic Intelligence}

Gardner has described Linguistic intelligence as sensitivity to spoken and written language and the ability to use language to accomplish goals, as well as the ability to learn new languages. Linguistic intelligence is our ability to speak to each other in our daily conversation, or write a letter to someone, or perform any verbal activity. This intelligence includes the ability to manipulate the syntax or structure of language, the phonology or sounds of language, the semantics or meanings of language, and the pragmatic dimensions or practical uses of language. According to Gardner (1993), lawyers, public speakers, writers, and poets all possess high levels of linguistic intelligence. If students want to develop their linguistic intelligences while focusing on language learning, they can consider doing the following activities:

- Browse the library or bookstores regularly.

- Keep a diary.

- Play word game.

- Memorize a favorite song, poem, or story.

- Get together with friends and take turns to read the parts of a play.

\section{B. Logical/Mathematical Intelligence}

Gardner (1993) described logical/mathematical intelligence as the ability to study problems, to carry out mathematical operations logically and analytically, and to conduct scientific investigations. Gardner identified mathematicians, logicians, and scientists as persons who would possess high levels of this hypothesized intelligence. The kinds of processes used in the service of logical-mathematical intelligence include categorization, classification, inference, generalization, calculation, and hypothesis testing. People who prefer to use their logical-mathematical intelligence usually do well on standardized comprehension/written language tests. They like to solve abstract problems and often do so by trial and error. If students want to develop their logical/mathematical intelligence with particular focus on language learning, they can consider doing the following:

- Watch television shows about science.

- Visit the local science museum.

- Sequence events into story line.

- Carry and use technology calculators and games.

- Read about famous scientists and their discoveries, or detectives'stories.

\section{Spatial/Visual Intelligence}

This intelligence involves sensitivity to color, line, shape, form, space, and the relationships that exist between these elements. Spatial intelligence is the ability to comprehend mental models, manipulate and model them spatially and draw them in detail. People who prefer to use this kind of intelligence would rather draw a paragraph than write a paragraph. If students want to develop their spatial intelligences while focusing on language learning, they can consider doing the following activities:

- Work on Jigsaw puzzles involving language.

- Take a filmmaking class.

- Cut out favorite pictures from magazines and make a collage.

- Pay close attention to the television advertisement, films and videos they see.

\section{Musical Intelligence}

It is our ability to sing a song or chant to the tune of a radio melody. We often use this type of intelligence to alleviate stress, but musical intelligence may also make some students more attuned to accent and pitch in language study. People who are musically intelligent can usually hear music in their heads and learn song quickly. They like to play some musical instrument or spend hours listening to music on the radio or CDs. If students want to develop their musical intelligences within language learning, they can consider doing the following activities:

- Go to concerts with friends and families.

- Make a tape or CD of their favorite songs.

- Keep a record of all the music they hear during the day.

- Sing English songs in the shower.

- Listen to different kinds of music.

\section{E. Bodily-kinesthetic Intelligence}

Bodily-kinesthetic intelligence involves our ability to use the body to express feelings or desires. The Total Physical Response (TPR) approach to language teaching relies on the use of bodily-kinesthetic intelligence. People with this 
intelligence often choose careers as athletes, dancers, actors, models, mimes and so on. If students want to develop their bodily-kinesthetic intelligence with particular focus on language learning they can choose doing the following activities:

- Play sports in their neighborhood.

- Enroll in dance, drama or poetry class.

- Mime or act out a story.

- Learn cooking, gardening, woodworking, or car mechanics.

\section{F. Interpersonal Intelligence}

Interpersonal intelligence is expressed in our human relationships where we cooperate with each other or agree or disagree with each other. Gardner stated that teachers, clinicians, salespeople, politicians, and religious leaders all use interpersonal intelligence. The trait of interpersonal intelligence is the most common intelligence foreign language teachers use. Kagan (2000) suggests that these skills can be activated by cooperative learning structures. If students want to develop their interpersonal intelligence with particular focus on language learning they can choose doing the following activities:

- Join some clubs at school or in their neighborhood.

- Have a party or invite one or two people they do not know very well.

- Interact with at least one person (out of class) each day.

- Be a people watcher. Go to a busy place where English is likely to be used and spend time watching people interact with one another.

\section{G. Intrapersonal Intelligence}

Intrapersonal intelligence, as conceptualized by Gardner, includes the awareness of one's own desires, fears, and abilities, and also using this information to make sound life decisions. Intrapersonal intelligence allows us to be independent, appreciate time alone, and be self-reflective. Intrapersonal intelligence, as described by Gardner, is also somewhat related to metacognition in general and to the ability to self-monitor in particular. That is, the individuals with high intrapersonal ability should be aware of what they know as well as what they do not know. People with this kind of intelligence often become therapists, writers, and religious leaders. If students want to develop their intrapersonal intelligence with particular focus on language learning they can choose doing the following activities:

- Think about their goals and their hopes for future.

- Attend religious services.

- Record their thoughts and feelings in a daily journal.

- Engage in activities that make them feel more confident about themselves.

- List strengths of their language learning and areas in which they need assistance.

\section{H. Naturalistic Intelligence}

Gardner (1999) described a naturalist as one who is able to recognize and classify objects. According to Gardner, hunters, farmers, and gardeners would have high levels of naturalistic intelligence, as would artists, poets, and social scientists, who are also adept at pattern-recognition. As described above, a central element of Gardner's naturalistic intelligence is the capacity to categorize objects according to salient similarities and differences among them. This ability is critically involved in the generation of meaningful taxonomies of both living and non-living objects.

People who use this intelligence often are always concerned with observing, classifying, and understanding the parts of the physical environment as well as showing understanding of natural phenomena. If students want to develop their naturalistic intelligence with particular focus on language learning they can consider doing the following:

- Be involved in a hobby that includes nature such as watching a bird.

- Enjoy studying environment, nature, plants and animals.

- Read books and magazines or watch television shows or movies that feature nature.

- Talk about favorite pets or preferred natural places to their classmates or friends.

\section{Existential Intelligence}

Gardner (1999) considered existential intelligence as the intelligence of understanding in a large context or big picture. It is the capacity to tackle deep questions about human existence, such as the meaning of life, why we die, what my role is in the world. This intelligence seeks connections to real world and allows learners to see their place in the big picture and to observe their roles in the classroom, society and the world or the universe. Existential intelligence includes aesthetic, philosophy, and religion and emphasizes the classical values of beauty, truth and goodness. Those with a strong existential intelligence have the ability to summarize and synthesize ideas from across a broad unit of study.

\section{Multiple InTELLigenCES Domains}

According to McKenzie (2002) multiple intelligences consist of three domains: the analytical, introspective and interactive domains. These three domains serve as an organizer for understanding the fluid relationship of the 
intelligences and how the intelligences work with one another. Teachers can plan lessons and units which effectively address all of the intelligences in the classroom. Figure 1. below presents the three domains.

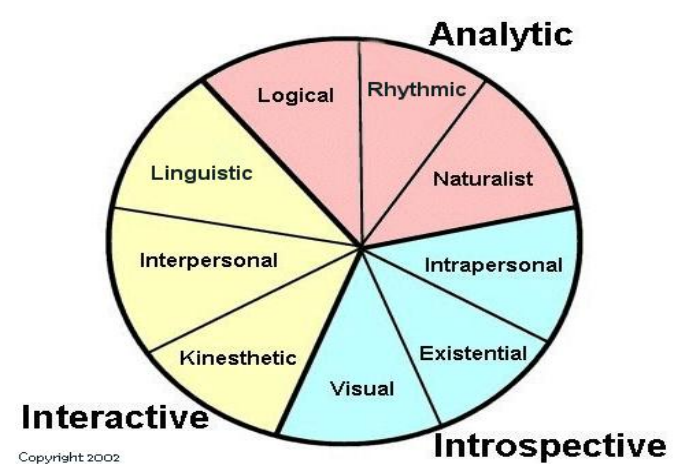

Figure 1. Multiple Intelligences Domains

What follows is a presentation of each domain and its sub-branches in details.

\section{A. The Analytical Domain}

According to McKenzie (2002), the analytic domain consists of the logical, musical and naturalist intelligences. These are the intelligences that promote analysis of knowledge that is presented to the learner. These three intelligences are considered analytic because they promote the processes of analyzing and incorporating data into existing schema, even though they may have other components. The analytical intelligences are by their nature heuristic processes.

\section{B. The Interactive Domain}

McKenzie (2002) indicates that the interactive domain consists of the linguistic, interpersonal and kinesthetic intelligences. These are the intelligences that learners typically employ to express themselves and explore their environment. These three intelligences are regarded as interactive because they typically invite and encourage interaction to achieve understanding. Even if a student completes a task individually, s/he must consider others through the way s/he writes, creates, constructs and makes conclusion. The interactive intelligences are by their nature social processes (McKenzie, 2002).

\section{The Introspective Domain}

The introspective domain consists of existential, intrapersonal, and visual intelligences. These are the intelligences that have a distinctly affective component to them. These intelligences are characterized as introspective because they require a looking inward by the learner, an emotive connection to their own experiences and beliefs in order to make sense of new learning. The introspective intelligences are by their nature affective processes (McKenzie, 2002).

These domain classification indicates that intelligence consists of different constructs supporting the idea of Gardner and his colleagues that there are different types of intelligences.

\section{SLA Approaches to Intelligence}

As it was mentioned earlier, during the history of language teaching and learning, many approaches to SLA have been proposed each one looking at the phenomenon of language learning from a different perspective. One of the important issues which have drawn the attention of many theories is intelligence. Due to the importance of intelligence as a significant individual characteristic which affect the process of SLA, different theories have given a different definition as well as a different role to this factor.

With regard to this point, the approach of behaviorism throws out any and all concept of consciousness, awareness, thought, will, etc., because the behaviorists believe that if it "can't be seen in a test tube" or "quantified" in some way then it doesn't exist. This is absurd because each of us knows fully well that we are conscious, have thoughts, act on will and are aware. The theories and practices of behaviorism are anti-mind and anti-spiritual. This denial and suppression of man's mind is the actual reason for much of what is wrong in modern societies. When the mind is denied so is everything that emanates from it, including ideas, thought, reason, hope, creativity, imagination, will, intention, awareness, consciousness, responsibility, attention, and morality. They attribute particular importance to "verbal behavior", because speech enable behaviorist theory to deal with such mentalistic concepts as "thinking" which is reinterpreted as subvocal verbalization (Watson, 1919, cited in Stern 1983, p. 293). They discard the "being" part of the "human being", keeping only the "human" or animal part. The term by itself displays the concept that we are each a combination of two notions: the physical, human, or animal part, and the invisible mind, being or spiritual part. The things such as creativity, reason, intelligence, understanding, communication, and responsibility come solely from the mind. Their methods are used to change the behavior only by imitation and reinforcement. Behavior should be altered by appealing to reason, intelligence, and one's observational abilities, with the result of personally making decisions, setting goals, and using intention to control one's self-determined actions (i.e. behavior). This depends on open communication between thinking beings. 
The other psychology of learning is Cognitivism. Cognitivists believe in the "single intelligence" based upon the unilinear construct of "general intelligence"; that intelligence is a true, heritable, biologically-based mental faculty that can be studied by measuring a person's reaction to cognitive tasks. Cognitivists who believe in information processing view of intelligence imagine that language aptitude is due to intelligence in general and argue that students with high intelligence learn faster and better and also their language skills are generally superior to those of less gifted children.

Genetic researches have also shown the potential complexity of the human genetic landscape. According to "generalist genes hypothesis" proposed by Plomin et al. (2007, cited in Dornyei, 2009, p. 193), one of the most important recent findings from quantitative genetic research has been the observation that same set of genes is largely responsible for genetic influence across a broad area of academic abilities. It was found that most genes associated with a particular learning ability (e.g. reading) would also be associated with other learning abilities such as mathematics, and even between relatively distant domains such as English and mathematics. Moreover, some genes associated with learning abilities and disabilities in general appear to have a broader impact, encompassing other cognitive abilities such as memory and spatial ability. Brody (2005, p. 121) points out that although the heritability of general intelligence implies genetic links, not many of the specific genes responsible for this intelligence factor have been identified, and neither has it been established how heritable dispositions interact with the social structures that influence social outcomes.

Another approach to the study of language learning is Socioculturalism. It believes in Triarchic theory of intelligence proposed by Sternberg (1985) that provides a more comprehensive description of intellectual competence than traditional differential or cognitive theories. This theory argues about three aspects of intelligence Analytic, Creative, and Practical intelligence. It is not against the validity of " $\mathrm{g}$ " factor; instead, the theory posits that general intelligence is part of analytic intelligence, and only by considering all three aspects of intelligence can the full range of intellectual functioning be fully understood. More recently, the triarchic theory has been updated and renamed the Theory of Successful Intelligence by Sternberg (2002). The three aspects of intelligence are referred to as processing skills.

Constructivism and developmental approach to the study of intelligence also believe in the impact of intelligence on learning a language. According to Piaget's theory of cognitive development, intelligence is the basic and main mechanism of ensuring equilibrium in the relations between the person and the environment. This is achieved through the actions of the developing person on the world. Piaget (1972) described four main periods or stages in the development towards completely equilibrated thought and problem solving. In terms of Ausubel's meaningful learning model, high intelligence would no doubt imply a very efficient process of storing items that are particularly useful in building conceptual hierarchies and systematically pruning those that are not useful. But in relating intelligence to second language learning, is it simply that an intelligent person will be able to learn a second language more successfully because of greater general intelligence? In the section below, the role and the effect of intelligence in SLA will be discussed in more details.

\section{INTELLIGENCE AND SLA}

Based on traditional definition, intelligence may have little to do with one's success as a second language learner. People with a wide range of IQs have proven to be successful in acquiring a second language. Traditionally, schools have emphasized the development of logical intelligence and linguistic intelligence (mainly reading and writing). While many students function well in this environment, there are those who do not (Richards \& Schmidt, 2002, p. 346). Dornyei (2009, p. 60) argues that when intelligence tests were first introduced at the beginning of the 20th century, nobody really knew what they were measuring except that they worked because they were effective in separating bright and slow children in schools. Distinguishing three types of intelligence - analytical (the ability to analyze, compare, and evaluate), creative (the ability to produce novel solutions to problems), and practical (the capacity to adapt, to shape, and to select environments suited to one abilities) intelligence, Sternberg (2002), argues that intelligence tests have generally targeted analytic and, to a lesser extent, creative intelligence because teaching methods have typically emphasized these.

Gardner (1983) attached other important attributes to the notion of intelligence that could be crucial to second language success. He proposed a controversial theory of intelligence. Gardner's theory of MI belongs to the group of instructional philosophies that focus on the differences between learners and the need to recognize learner differences in teaching. He also addresses the question whether traditional IQ tests are truly scientific. Gardner argues that traditional definition of intelligence in psychometrics (IQ tests) does not sufficiently describe the wide variety of cognitive abilities humans display. He argues that psychometric tests address only linguistic and logical plus some aspects of spatial intelligence. He argues that students will be better served by a broader vision of education, wherein teachers use different methodologies, exercises and activities to teach all students, not just those who excel at linguistic and logical intelligence.

The application of the theory of multiple intelligences varies widely. It runs the gamut from a teacher who, when confronted with a student having difficulties, uses a different approach to teach the material, to an entire school using MI as a framework. When humanism started to have a decisive impact on education in the 1960s, the conventional, authoritative teacher-centered instruction gave way to the learner-centered mode of instruction. Educators began paying more attention to the impact of affective factors such as feelings, emotions, anxiety, frustration, motivation, and 
confidence on the process of learning (Lin, 2000). There has also been a maturing of some innovative English Language Teaching approaches, methods, and techniques over the last 20 years. Every English Language Teaching method or technique with its specific emphasis has been developed to meet students' different needs or interest. These approaches can be linked to Gardner's (1993) intention of developing or using different kinds of intelligences. The Silent Way, for example, emphasizes the development of students' inner thinking (intrapersonal intelligence). Total Physical Response, however, emphasizes language learning through physical action (bodily/kinesthetic intelligence). Suggestopedia uses drama and visual aids as keys to unlock a student's learning potential; in this approach music plays the greatest role in facilitating learning (musical intelligence). Both the Communicative Approach and Cooperative Learning seem to place its greatest emphasis upon the importance of interpersonal relationship (interpersonal intelligence) to language learning. Yet specific activities can involve students in each of the other intelligences as well. Similarly, Whole Language learning has at its core the cultivation of linguistic intelligence. It is suggested here that MI theory can provide a way for all teachers to reflect upon their best teaching methods, and to figure out the reason why some methods they use work well for some students but not for others. It also may help teachers expand their current teaching repertoire to include a broader range of techniques, materials, and methods for reaching an ever wider and more various range of learners, since it may be that some students have not responded well in the past because their preferred intelligences were not being stimulated by the teaching approach used (Armstrong, 2000; Lin, 2000).

As it is seen, the MI theory has an important role in education, in general, and in language teaching and learning, in specific. The principles of multiple intelligences offered by Gardner are: (1) Emphasis on the development of certain intelligences; (2) Utilizing of all intelligences in developing different teaching methods; (3) Based on the concept of multiple intelligences, instructors should review lesson plans and ensure they have variety, fairness and richness; (4) Provide students with the opportunity to choose learning activities and assessment methods; (5) Provide students with the opportunity to use the dominant intelligences to develop the weaker intelligences; (6) Use the intelligences to fully comprehend broad subjects (Gardner, 1983). Furthermore, the importance of the multiple intelligences in education has been counted: (1) Highlighting uniqueness of each student; (2) Bring out the students' dominant intelligences; (3) Dominant intelligence helps learning; (4) Variety of learning experiences; (5) Multiple intelligences teaching; (6) Variety of assessment methods; (7) Variety of means of expression (Hoerr, 2000).

On the other hand, some other researchers have concentrated on the problems with this theory. For instance, Troub (1998, cited in Brody, 2010) notes that Gardner's system has not been accepted by most academics in intelligence or teaching. Many psychologists (i.e. Klein, 1988, p. 106) feel that a differentiation of the concept of intelligence is not supported by empirical evidence, but many educationalists support the practical value of the approaches suggested by the theory.

Also, Sternberg (1988, p. 42, cited in Brody, 2010) calls MI model "a theory of talents, not one of intelligences", arguing that Gardner is not expanding the definition of the word "intelligence", rather, he denies the existence of intelligence as traditionally understood and instead uses the word "intelligence" whenever other people have traditionally used words like "ability".

Another criticism of Gardner's theory is that it is fundamentally ambiguous because it has three paradoxes: (1) there are several relatively independent, coherent content-specific cognitive modules, called intelligences, (2) these intelligences interact, operating on one another's contents, and (3) each intelligence consists of sub-intelligences that can operate independently. This ambiguity leads to a kind of ambiguity that makes it difficult, perhaps impossible, to either prove or deny MI theory; in Popperian terms, it is unfalsifiable (Klein, 1988, p. 105).

In another effort, Goleman (1995, p. 291, cited in Brown, 2000, p. 101) proposes emotional theory and explains about the bias of traditional definitions and tests of general intelligence, puts emotion at the highest level up a hierarchy of human abilities and argues that "the emotional mind is far quicker than the rational mind".

\section{CONCLUDING REMARKS}

As mentioned earlier, individual cognitive and affective factors like aptitude, introversion/extroversion, fieldindependent/field-dependent, motivation, empathy, anxiety, self-confidence, self-regulation, inhibition, and many others have an important influence on the speed and ease of second language learning and this is why some people are more successful language learners while others are not. In the same direction, one of the important individual factors which was discussed in detail through this literature is intelligence. It is proper to regard intelligence as the correct term to characterize the innate, genetically endowed ability. Gardner's (1983) multiple intelligences theory consisting of at least seven categories is shown to be significant in relation to both language teaching and learning. According to Smith (2001) as a theoretical construct the theory of Multiple Intelligences suggests an explanation for intelligence which embraces human diversity and emphasizes the importance of the cultural contexts within which intelligence operates. At the cognitive level, Multiple Intelligences theory develops a framework which assists in explaining individual variations in adult second language learning proficiency. Despite the fact that there are many different definitions of intelligence and its effect on second language learning, we can conclude that there is clear evidence on the relationship between intelligence as a cognitive factor and second language acquisition. Mitchell and Myles (2004) state "second language students who are above average of formal measures of intelligence or general academic attainment tend to do well in second language learning, at least in formal classroom settings" (p. 25). Gardner's theory of multiple 
intelligences, as it was shown, is very closely related to language teaching and has certain applications for teachers. With regard to classroom instruction, teachers should provide conditions that encourage students to use all kinds of intelligence. Although some students might prefer to use just certain types, teachers should recognize and teach to a broader range of talents and skills that depend on a variety of intelligences. Since teachers themselves might have preferences for certain intelligences, one important implication of MI theory is for teachers to start identifying their own intelligence profiles so that they can determine their best or preferred teaching strategies taking into account human differences. After identifying their own intelligence preferences and the impact this may have on their teaching, the second implication is to profile the students. Christison (1998) found that the more awareness the learners have of their intelligence profile, the more they are able to utilize this knowledge in their future learning. Teachers can also take advantage of exercises, activities, techniques and materials that help provoke their students' intelligences and thus encouraging them to make use of different intelligences in the process of learning. Another implication of MI theory for teachers is that by paying attention to all kinds of intelligence, teachers can try to design a syllabus taking advantage of a variety of games, stories, music, images as well as different tools and materials intended to mix all intelligences. This, in turn, is useful for teachers in that they can awaken all kinds of intelligences in their students. Also, it helps strengthen the creativity in teachers in that it frees teachers from relying just on textbooks and encourage them to design a syllabus appropriate at the level of their students.

\section{REFERENCES}

[1] Armstrong, T. (2000). Multiple intelligences in the classroom. Alexandria, VA: ASCD.

[2] Armstrong, T. (2009). Multiple intelligences in the classroom ( $3^{\text {rd }}$ Ed.). Alexandria, Virginia USA.

[3] Brody, N. (2005). Phenotypes and genotypes of personality and intelligence: Similarities and differences. In A. Eliasz, S. E. Hampson, \& B. D. Raad (Eds.). Advances in personality psychology, (pp. 113-138). New York: Psychology Press.

[4] Brody, N. (2010). Some critiques of Howard Earl Gardner's Multiple Intelligences theory. Retrieved June 4, 2011 from www.igs.net/ cmorris/critiques.html

[5] Brown, H. D. (2000). Principles of language learning and teaching $\left(4^{\text {th }}\right.$ Ed.). New York: Addison Wesley Longman.

[6] Chapman, C., \& Freeman, L. (1996). Multiple intelligence: Centers and projects. Retrieved June, 3, 2011 from http://www.metagifted.org/topics/gifted/multipleIntelligences/

[7] Chastain, K. (1988). Developing second language skills: Theory and practice. Orlando: Harcourt Brace Jovanovich.

[8] Christison, M. (1998). An introduction to multiple intelligence theory and second language learning. In J. Reid, (Ed.), understanding second learning styles in second language classroom (pp. 3-13). New Jersy: Prentice Hall, Inc.

[9] Dornyei, Z. (2009). The psychology of second language acquisition. Oxford: Oxford University press.

[10] Ellis, R. (1985). Understanding second language acquisition. Oxford: Oxford University Press.

[11] Ellis, R. (2008). The study of second language acquisition $\left(2^{\text {nd }}\right.$ Ed.). Oxford: Oxford University Press.

[12] Gardner, H. (1983). Frames of mind: The theory of multiple intelligences. New York: Basic Books.

[13] Gardner, H. (1993). Multiple intelligences. New York: Basic Books.

[14] Gardner, H. (1999). Intelligence reframed: Multiple Intelligences for the $21^{\text {st }}$ century. New York: Basic Books.

[15] Gardner, H. (2009). Multiple intelligences around the world. New York: Basic Books.

[16] Hernandez, J. V., Noruzi, M. R., \& Sariolghalam, N. (2010). Multiple intelligences as a new paradigm in the education of Mexico. International Journal of Education, 2(1), 1-18.

[17] Hoerr, T. R. (2000). Becoming a multiple intelligences school. Alexandria, VA: ASCD.

[18] Kagan, S. (2000). Multiple intelligences and second language learning. New York: National Professional Resources, Inc.

[19] Klein, P. D. (1998). A response to Howard Gardner: Falsifiability, empirical evidence, and pedagogical usefulness in educational psychologies. Canadian Journal of Education, 23 (1), 103-112.

[20] Lin, P. Y. (2000). Multiple intelligence theory and English language teaching. Retrieved June 5, 2011, from:http://highschool.english.nccu.edu.tw/paper/ying.doc

[21] McKenzie, W. (2002). Multiple intelligences and instructional technology: A manual for every mind. Eugene, OR: International Society for Technology in Education.

[22] Mitchel, R., \& Myles, F. (2004). Second language learning theories. (2nd Ed.). London: Hodder Arnold Publication.

[23] Piaget, J. (1972). The principles of genetic epistemology. New York: Basic Books.

[24] Richards, J. C., \& Schmidt, R. (2002). Longman dictionary of applied linguistics. ( ${ }^{\text {rd }}$ Ed.). London: Pearson Education Limited.

[25] Smith, E. (2001). Implications of multiple intelligence theory for second language learning. Post script, 2(1), 1-21.

[26] Spolsky, B. (1989). Conditions for second language learning. Oxford: Oxford University Press.

[27] Stern, H.H. (1983). Issues and options in language teaching. Oxford: Oxford University Press.

[28] Sternberg, R.J. (1985). Beyond IQ: A triarchic theory of human intelligence. New York: Cambridge University Press.

[29] Sternberg, R. J. (2002). The theory of successful intelligence and its implication for language aptitude testing. In P. Robinson (Ed.). Individual differences and instructed language learning, (pp. 13-44). Amsterdam: John Benjamin B.V.

[30] Wagner, R. K., \& Sternberg, R. J. (1985). Practical intelligence in real-world pursuits: The role of tacit knowledge. Journal of Personality and Social Psychology, 49, 436-458. 


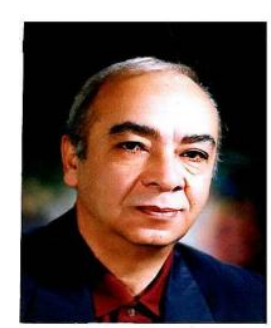

Parviz Maftoon is Associate Professor of teaching English at Islamic Azad University, Science and Research Branch, Tehran, Iran. He received his Ph.D. degree from New York University in 1978 in Teaching English to Speakers of Other Languages (TESOL). His primary research interests concern EFL writing, second language acquisition, SL/FL language teaching methodology, and language syllabus design. He has published and edited a number of research articles and books. He is currently on the editorial board of some language journals in Iran.

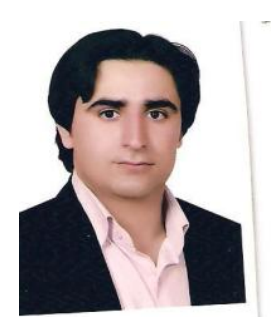

Saeid Najafi Sarem is a Ph.D student of TEFL in Islamic Azad University, Science and Research branch, Tehran, Iran. He is the head of Sharif Language Institute in Asadabad, Hamedan, and he is currently teaching in Azad and Payamnoor universities in Hamedan. He is interested in teaching methodology and second language acquisition (SLA) studies and has presented many articles in different national and international conferences. He has got some publications in different national and international journals as well. 